\title{
Measuring Students Loyalty on Branded Smartphone in Indonesia
}

\author{
Rey Remantri Hardi* Susanto Siti Dyah Handayani \\ Master of Management, Universitas Muhammdiyah Yogyakarta, Indonesia. Jl. Brawijaya, Bantul, Daerah \\ Istimewa Yogyakarta, 55183
}

\begin{abstract}
Business competition in the field of technology such as gadgets is currently experiencing a fairly tight development. In a competitive market, competition is not only on tariffs and products but also on consumer perceptions. One brand of smartphone that has a good brand is the iPhone produced by the Apple company. This study aims to examine the effect of perceived quality, brand image and price perception on customer satisfaction and brand loyalty and test the effect of customer satisfaction on the loyalty of Iphone brands at Muhammadiyah University of Yogyakarta. The population in this study were all UMY students who used the iPhone. While the retrieval method uses the judgmental sampling method, namely the sampling technique based on certain criteria, namely UMY students who are active in the 2018/2019 school year and already have an iPhone smartphone more than 6 months, the sample in this study was 210 respondents. Data analysis methods include Descriptive Analysis and Quantitative Analysis with Structural Equation Modeling analysis techniques with AMOS 21 programs. The results of the study found that there was a positive and significant effect of perceived quality on customer satisfaction, there was a positive and significant influence of brand image on customer satisfaction, there was a positive and significant influence of price perception on customer satisfaction, there was a positive and significant effect on product quality on loyalty brand, there is a positive and significant influence of brand image on brand loyalty, there is a positive and significant influence of price perception on brand loyalty and there is a significant influence partially on variable customer satisfaction on brand loyalty on Iphone Smartphone products.
\end{abstract}

Keywords: perceived quality, brand image, perceived price, brand loyalty

DOI: $10.7176 / \mathrm{EJBM} / 11-12-09$

Publication date: April $30^{\text {th }} 2019$

\section{Background}

Along with the progress of the times supported by globalization, encouraging people to the needs of a very diverse range of gadgets, and of course as time goes on, new gadgets are emerging that can do everything to replace computer functions ranging from communication devices, online shopping, radio, browsing, games and social media. One brand of smartphone that has a good brand is the iPhone produced by the Apple company. Currently the iPhone has become a dream brand for teenagers, including students. In 2017 the first quarter APPLE was able to sell 50.8 million iPhones. Overall APPLE's income increased by 4.6\%, amounting to Rp.691 trillion. One of the reasons for the increase in sales of iPhone 7 Plus smartphones is that it is much bigger and more expensive. Based on Apple's revenue that comes from iPhone sales is $\$ 7$ billion or around 93 trillion. This shows that the company has experienced a revival that had previously experienced a decline, due to competition from its main competitor, Samsung. The results of Apple's report state that profits in the first three months of 2017 reached $\$ 11$ billion or as much as Rp. 146 trillion worldwide, and increased by 4.9\% compared to the period of 2016. (https://www.winnetnews.com). This phenomenon shows that consumer loyalty to iPhone products is very high. There are several factors that influence brand loyalty (brand loyalty) among them are perceptions of quality, brand image, price perception and customer satisfaction.

Quality is the overall characteristics and characteristics of a product or service that affect the ability to satisfy expressed or implied needs. Satisfying customers is a goal for profitability, because dissatisfied customers will easily move to another place and spend the item in that place. Kotler and Armstrong (2013) define customer satisfaction as a feeling of whether someone likes or dislikes a product after comparing the presentation of the product's achievements with expectations. This satisfaction can be felt by the customer if the service and trust in the goods purchased then the customer will feel comfortable and will not be easy to leave if the factor does not match the customer's needs.

Brand image can also influence customer satisfaction. The main purpose of brand and product management is to build a strong brand image which in turn produces large short-term and long-term profits (Aaker, 2013). According to Kotler and Armstrong (2013), an image or image is a set of beliefs, ideas and impressions that an individual has on an object. Companies must strive to create a positive brand image in the minds of customers so that customers remain interested in the products offered so that the company can still compete with competitors in the market.

In addition to quality and brand image, other factors that influence customer satisfaction are perceived prices. Price perception plays an important role in creating customer satisfaction. The reason customers switch to other 
smartphone brands is the reason for perceived prices. A high, unreasonable and unreliable price policy will negatively affect customer satisfaction. Customers want good quality products at affordable prices that they can buy easily and if there is a company providing this to customers it will build good long-term relationships with customers.

While customer satisfaction is a post-consumption evaluation, where an alternative chosen at least meets or exceeds expectations. In short the alternative is at least as expected by the customer. Satisfaction is the feeling of being happy or disappointed someone who appears after comparing between perceptions or impressions of the performance (results) of a product and its expectations (Kotler and Armstrong, 2013). This opinion can be interpreted that satisfaction is a function of perception or impression of performance and expectations. If performance meets expectations, customers are satisfied. If the performance exceeds the customer's expectations, they are very satisfied or happy.

Based on the results of the latest research released by the Indonesian Internet Service Providers Association (APJII, 2016), the younger generation in the age range of 20-24 years has a penetration rate of more than 80 percent of internet users in Indonesia. The results of this research reinforce the results of Google's research on smartphone users in Indonesia, which shows that most smartphone users are a segment of young people aged between 18-24 years, living in cities and highly educated. On the basis of these data, in this study using a sample of Muhammadiyah Yogyakarta University students. The reason is that aside from the ease of data collection, there are quite a lot of students at UMY who use Iphone products. The results of the pre-survey conducted on 30 UMY students randomly showed that as many as 13 students or $43.3 \%$ used an Iphone. Based on these phenomena, the authors are interested in conducting research on the Effect of Quality Perception, Brand Image and Price Perception on Brand Loyalty with Satisfaction as a Mediating Variable on Iphone Products at Muhammadiyah University Yogyakarta Students.

\section{Literature Review}

2.1 Perceived Quality

Durianto and Darmadi (2011) define perceived quality as a customer's perception of the overall quality or superiority of a product or service related to what the customer expects. Perceived quality reflects the customer's overall feeling about a brand. To understand the perceived quality of a brand, it is necessary to measure dimensions related to product characteristics. Regarding the dimensions of perceived quality, Durianto and Darmadi (2011) refer to the opinion of David A. Garvin (1996), dividing it into seven, namely performance, service, resilience, reliability, product characteristics, compatibility with specifications and results. According to Kotler and Armstrong (2013) consumer satisfaction or dissatisfaction will influence consumer behavior. Customer satisfaction is a situation where the wishes, expectations and needs of customers are met. A service is considered satisfactory if the service can meet the needs and expectations of consumers. Consumer satisfaction measurement is an important element in providing better, more efficient and more effective services, if consumers feel dissatisfied with a service provided, then the service can be assured of being ineffective and inefficient. With the satisfaction of consumers it will be able to create customer loyalias

\subsection{Brand Image}

Customers usually develop brand trust for each brand according to their product attributes. Brand image is a set of beliefs held by customers towards certain products (Kotler and Armstrong, 2013). The image of a brand is the second dimension of customer-based brand knowledge. Customers in buying and consuming something not only expect only goods, but there is something else. Something else is in accordance with the image formed in him. A company has an interest in providing information to the public in order to form a good image. Brand image can be made like goods in a factory, but the image is the impression obtained in accordance with the understanding and knowledge of someone about something. The image that is in the company is formed from how the company carries out its operational activities which have the main foundation in terms of service.

Marketers say that "giving a brand" is a series and the most important part of marketing. The American Marketing Association (AMA) in Kotler \& Armstrong (2013) defines brands as follows: "Brands are names, terms, signs, symbols, designs or combinations of things - these things, which are intended to define goods or services from a person or group of sellers and to differentiate from competitors' products.

\subsection{Perceived Price}

According to Kotler and Keller (2007) Perception is a process used by individuals to choose, organize and interpret input information to create a picture of the world that has meaning. Perception is a process carried out by individuals to select, organize, and interpret stimuli into images that are meaningful and reasonable about the world (Schiffman and Kanuk, 2007). In a narrow sense, price is the amount of money paid for goods or services.

According to Kotler and Armstrong (2013), prices are the amount of money charged for a product or service, or the amount of values exchanged by customers to get benefits or use products and services. While value is the 
consumer's estimate of the total ability of a product to meet its needs, one will imagine the nature of the ideal product. For him in a product there are obstacles to possessing these products, namely costs. So in purchasing consumers will choose products that provide the highest value for the price. In choosing the product, it is based on the consumer's papacy on the value obtained from a product and the costs that must be borne. For the company. Prices are determined by the amount of production costs plus the desired profit margin.

According to Sehifmann and Kanuk (2007) explaining perceptions is a process of an individual in selecting, organizing and translating information stimuli that come into a comprehensive picture. Perception has a strong influence on consumers. One of the factors that influence consumers is the perception of price. Thus the perception of price is a perception given by consumers of the amount of money charged for a product or service, or the amount of values exchanged by customers to get benefits or use products and services.

\subsection{Satisfaction}

Kotler \& Armstrong (2013) defines customer satisfaction as a feeling of whether someone likes or dislikes a product after comparing the presentation of the product's achievements to expectations. According to Tjiptono (2010) customer satisfaction or dissatisfaction is the customer's response to the evaluation of dissatisfaction (disconfirmation) that is felt between previous expectations or other performance expectations and the actual performance of the product that is felt after using it. Churchill (in Aydin 2006) customer satisfaction is an output where the results of customer comparison of expectations before purchase with perceptions after purchase and receipt of costs. From various it can be concluded that the notion of customer satisfaction includes the difference between expectations and perceived results.

Customer satisfaction is the key to creating customer loyalty. Many benefits are received by the company by achieving a high level of customer satisfaction, which is in addition to increasing customer loyalty but can also prevent customer turnover, reduce customer sensitivity to prices, reduce marketing failure costs, reduce operating costs caused by increasing numbers of customers, increase advertising effectiveness, and improve business reputation.

\subsection{Brand Loyalty}

According to Durianto and Darmadi (2011) brand loyalty is a measure of customer relationship to a brand. According to Mowen and Minor, (2012) brand loyalty is defined as the degree to which customers have a positive attitude towards a brand, have customer commitment and tend to continue to buy products with a particular brand in the future. Thus, brand loyalty is directly influenced by customer satisfaction / dissatisfaction with certain brands. Consistent purchases over time are indicative of brand loyalty, repeat purchase behavior is assumed to reflect strong reinforcement or stimulus. So, the measurement that a consumer is loyal or not seen from the frequency and consistency of his buying behavior towards a brand. Loyalty is a customer's commitment to a brand that may not only be reflected by continuous buying behavior. Consumers may often buy a certain brand because of its low price, and when the price goes up consumers turn to other brands.

\section{Hypothesys Development}

3.1. Relationship between Perceived Quality on Satisfaction

The quality of a product is determined by the customer through the characteristics that exist in a product and service, where satisfaction and failure of the customer is influenced by the value obtained by consuming a product. According to Mowen and Minor (2012), that product quality has a direct effect on customer satisfaction. The relationship between service quality and customer satisfaction is important for companies, and researchers, because companies (service providers) need to know whether the company's goals have satisfied customers with the company's performance at the maximum level (Cronin and Taylor, 1992 in Lien-Ti Bei and Chiao 2006) . Kotler and Armstrong (2013) also argue that good quality products will create customer satisfaction. In turn, customers are happy, loyal and will recommend to others about the company and its products. The results of Dib and Al-Msallam (2015) found that perceptions of quality had a positive and significant effect on customer satisfaction. Based on these arguments, the first hypothesis of this study is:

H1: Perceived quality has a positive effect on Satisfaction

\subsection{Relationship between Brand Image on Satisfaction}

The company's image is believed to create an effect on customer satisfaction. When customers are satisfied with the services provided, their attitude towards the company increases. This attitude will then affect the satisfaction they feel for the company. A well-managed brand image will have positive consequences. Impression is one of the basic characteristics of a modern marketing orientation, namely through giving more attention and creating a strong brand. The implication of this is that the brand of a product creates the image of the product itself in the minds of consumers and makes the basic motivation for consumers in choosing a product (Aaker 2013). This is supported by the findings of Dib and Al-Msallam 2015, which states that brand image has a role in marketing an organization 
because it has the potential to influence consumers' perceptions and expectations about the goods or services offered and ultimately affect consumer satisfaction and loyalty. With a good corporate image this helps people make the decision to transact at the company. Because you already believe in that good reputation, of course people don't buy only once, but they can be repeated many times. The results of Suryati and Krisna (2015) and Lasander's (2013) study found that brand image had a significant effect on customer satisfaction. Thus the second hypothesis of this study is

H2: Brand Image has a positive effect on Satisfaction

\subsection{Relationship between Perceived Price on Satisfaction}

According to Kotler and Keller (2007) Perception is a process used by individuals to choose, organize and interpret input information to create a picture of the world that has meaning. Perception is a process carried out by individuals to select, organize, and interpret stimuli into images that are meaningful and reasonable about the world (Schiffman and Kanuk, 2007). On the other hand, it is also possible that consumers use prices as a guide. This implies that lower monetary prices or perceived prices do not guarantee higher satisfaction. Consumers usually value prices and service quality with the concept of "equity", then produce their level of satisfaction or dissatisfaction. Recently, the marketing literature shows the tendency of researchers to price in relation to customer satisfaction (Hermann et al., 2007). Prices refer to consumers' judgments about whether the seller's price is reasonable, acceptable or justifiable (Dib and Al-Msallam, 2015). Price loyalty is a very important problem that leads to satisfaction. Charging fair prices helps develop customer satisfaction and loyalty. Research has shown that the customer's decision to accept a certain price has a direct influence on the level of satisfaction and loyalty and indirectly (Martin et al. 2008). In Dib and Al-Msallam (2015) research and Suryati and Krisna (2015) research found that prices have a significant effect on customer satisfaction. In this context, this research then proposes the following:

H3: Perceived price has a positive effect on Satisfaction

\subsection{Relationship between Perceived Quality on Loyalty}

The impression of quality created by a brand can provide a positive assessment of a brand. When the brand is known, consumers will perceive the quality of the product. Quality perceived by consumers will make it easier for products to be accepted by the market. A good quality perception can help all elements of the marketing program become more effective. If perceptions of quality are high, chances are that advertising and promotion will be effective. Brands with a strong perception of quality will have a greater chance of success in brand extension policies. This perception of quality will shape the customer's overall perception of a product's quality in the minds of consumers (Durianto and Darmadi, 2011). The overall perception of the quality of a product can determine the value of the product and influence the equity of the product. Perception of quality is a component of brand value, therefore the perception of high quality will encourage consumers to prefer the brand compared to competing brands. Positive perceived quality will encourage consumers to buy and create loyalty to the product. Furthermore, considering that consumer perceptions can be predicted, if the perception of quality is negative, the product will not be liked and will not last long in the market. Conversely, if the perception of customer quality is positive then the product will be preferred (Durianto and Darmadi, 2011). Thus, the higher the perceived quality of the customer will tend to encourage consumers to be loyal to the product that has been perceived so that it can be said that the perception of quality is related to customer loyalty. Pramono's (2011), and Utami and Saryadi's (2016) research findings consistently found that quality perceptions / perceptions had a significant positive effect on brand loyalty. Based on these arguments, the fourth hypothesis of this study is:

H4: Perceived quality has a positive effect on Loyalty

\subsection{Relationship between Brand Image on Loyalty}

The relationship between brand image and customer loyalty lies in desires and preference for a brand is the attitude of the customer. In many ways, certain brand images often influence whether customers will be loyal or not. Good perception and customer trust in a particular brand will create customer buying interest and even increase customer loyalty to certain products. The connecting theory between brand image and customer loyalty is quoted from Rangkuti (2006), which says that if a customer thinks that a certain brand is physically different from a competitor's brand, the brand image will be attached continuously so that it can form a certain brand loyalty called brand loyalty. . The results of Dib and Al-Msallam (2015), Pramudyo (2012) found that brand image has a significant positive effect on brand loyalty. Thus the fifth hypothesis of this study is:

H5: Brand Image has a positive effect on Loyalty

\subsection{Relationship between Perceived Price and Loyalty}

Ti Bei and Ching Chiao (2006) find that fair price perceptions have a positive influence both directly and indirectly (through customer satisfaction) on brand loyalty. From the customer's perspective, price is what is given or 
sacrificed to get a product. It is possible to display repeat purchase behavior intentions. On the other hand, if customers do not feel that their sacrifice is valuable, they may not buy again, even when they are satisfied with the quality of a product if the price does not provide justice will reduce customer loyalty. In the research Suryati and Krisna (2015) found that prices significant effect on brand loyalty. Based on this explanation, the sixth hypothesis of the study is:

H6: Perceived Price has a positive effect on Loyalty

\subsection{Relationship between Satisfaction on Loyalty}

Customer satisfaction is a post-consumption evaluation, where an alternative chosen at least meets or exceeds expectations. In short the alternative is at least as expected by the customer. Satisfaction is a feeling of pleasure or disappointment someone who appears after comparing between perceptions or impressions of the performance (results) of a product and expectations (Kotler and Keller, 2007). This opinion can be interpreted that satisfaction is a function of perception or impression of performance and expectations. If performance meets expectations, customers are satisfied. If the performance exceeds the customer's expectations, they are very satisfied or happy. Some studies such as Utami and Saryadi, (2016) and Pramono, (2011) find positive evidence that there is a relationship between customer satisfaction and customer loyalty. Based on this, the third hypothesis of this study is:

H7: Customer Satisfaction has a positive effect on Loyalty

Based on the study of theory and the study of previous research, the framework of thinking can be described as follows:

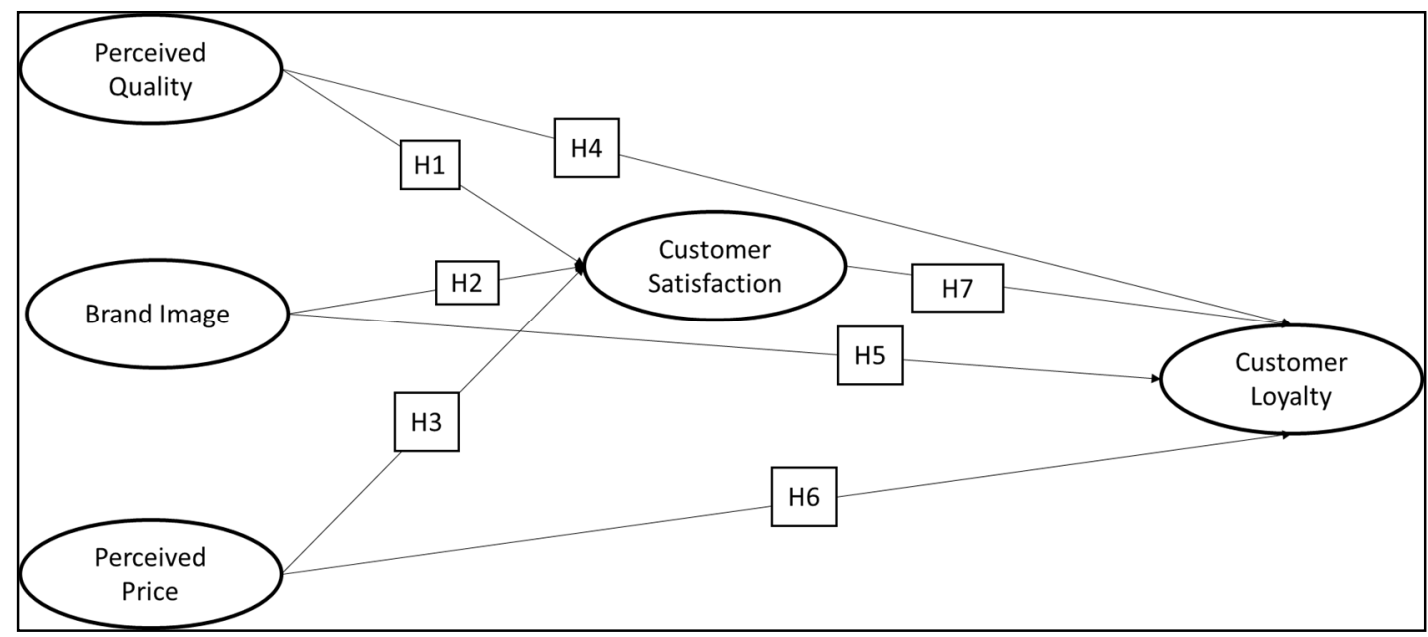

Figure 1. Research Model

The picture above explains the relationship that occurs from each variable so as to create a hypothesis that has been formulated above.

\section{Research Method}

The population used in this study is all UMY students who use the iPhone. While the sample of this study was 210 respondents who were considered to have adequately represented the population studied. The sampling technique uses a judgemental sampling method, namely sampling methods with certain considerations, such as UMY Economics Faculty students who have at least the iPhone in the last 6 months. The data in this study uses primary data.

Hypothesis testing is done by using the Structural Equation Modeling (SEM) method with the AMOS program. In AMOS SEM testing, the first step is testing various criteria for goodness of fit. The first action to be taken is to evaluate whether the data used can fulfill SEM assumptions, namely sample size, normality and linearity, outliers and multicollinearity and singularity, and have good goodness of fit.

\section{Result}

In this study 237 questionnaires were distributed and returned questionnaires were then processed as much as 210 . Based on the results of the profile analysis, respondents indicated that the majority of respondents were women, which amounted to $51.9 \%$ (109 people), the majority were between $21-24$ years, namely amounting to $43.3 \%$ (91 people), with pocket money between IDR.2,500,001 - IDR.3,000,000 which is $39.5 \%$ (83 people), and the type of product used is an Iphone 6 product that is equal to $45.2 \%$ (95 people).

In this study, goodness of fit indicators generally indicate that the measurement model used is acceptable. Below are each goodness of fit tests in the research model. 
Table 1. Measurement Model-Goodness of fit

\begin{tabular}{|l|c|c|c|}
\hline \multicolumn{1}{|c|}{ Goodness of Fit Index } & Hasil & Cut Off Value & Kriteria \\
\hline Likelihood Chi Square & 237,159 & Expected small & \multirow{2}{*}{ Not good } \\
\hline Probability & 0,000 & $\geq 0,05$ & Good \\
\hline CMIN/DF & 1,429 & $\leq 2,00$ & Good \\
\hline RMSEA & 0,047 & $\leq 0,08$ & Good \\
\hline GFI & 0,905 & $\geq 0,9$ & Marginal \\
\hline AGFI & 0,868 & $\geq 0,9$ & Good \\
\hline TLI & 0,952 & $\geq 0,9$ & Good \\
\hline CFI & 0,962 & $\geq 0.9$ & . \\
\hline
\end{tabular}

The results of goodness of fit obtained GFI $=0.905>0.9$, CMIN/DF $(1.429<2)$, RMSEA $(0.047<0.08)$, TLI $(0.952>0.9)$, and CFI $(0.962<0.90)$, indicating good model. While the Chi square value $(\mathrm{p}=0,000<0,05)$ in the criteria that are not good and AGFI is in the fairly good criteria (Marginal). By referring to the opinion expressed by Ghozali, the path model proposed in this study has met the assumptions of Goodness of Fit (good fit model) Testing the hypothesis with SEM Analysis obtained the results of the path as follows:

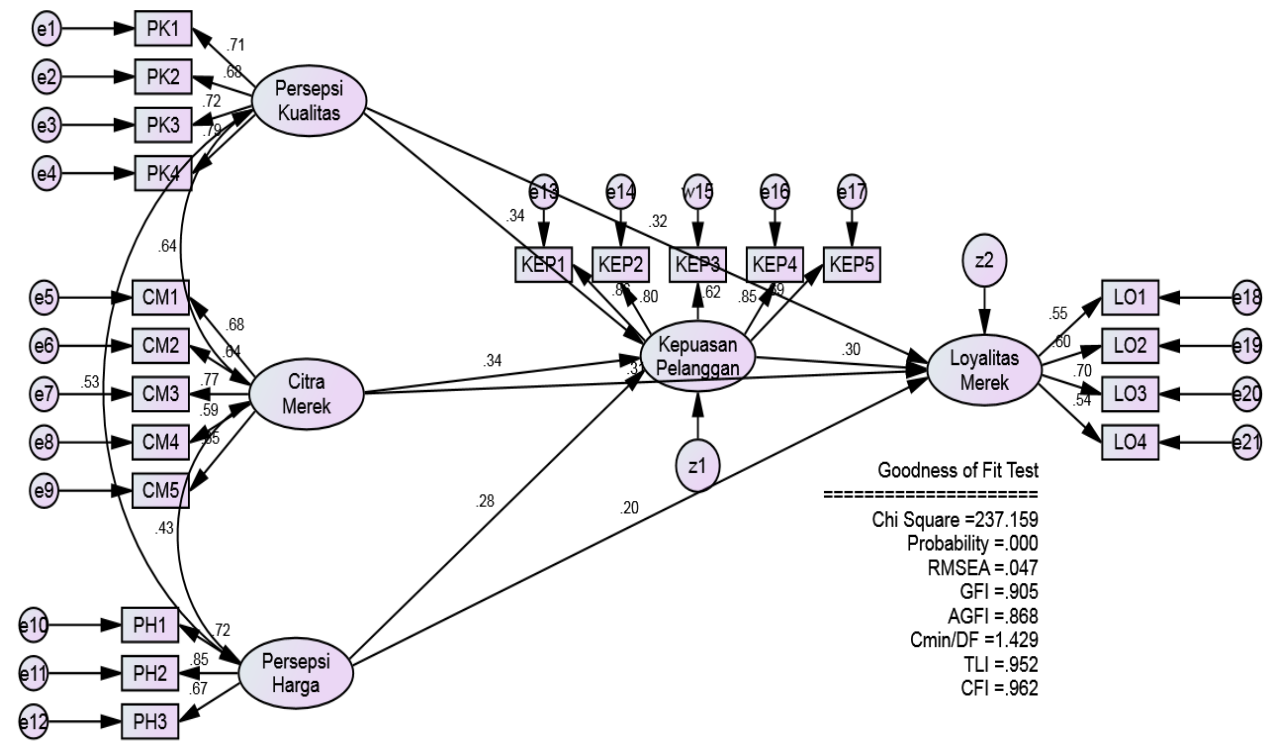

Figure 2. Research Model Testing Results

The picture above is a research model that has been applied in AMOS software.

Table 2. SEM Analysis Results

\begin{tabular}{|lcl|c|c|c|c|c|}
\hline & Hypothesys Test & Estimate & S.E. & C.R. & P & \\
\hline Satisfaction & $<--$ & Perceived Quality & 0.340 & 0.081 & 3.754 & 0.000 & H1 accepted \\
\hline Satisfaction & $<---$ & Brand Image & 0.340 & 0.091 & 3.841 & 0.000 & H2 accepted \\
\hline Satisfaction & $<---$ & Perceived Price & 0.281 & 0.081 & 3.829 & 0.000 & H3 accepted \\
\hline Loyality & $<---$ & Perceived Quality & 0.316 & 0.078 & 2.731 & 0.006 & H4 accepted \\
\hline Loyality & $<---$ & Brand Image & 0.306 & 0.086 & 2.730 & 0.006 & H5 accepted \\
\hline Loyality & $<---$ & Perceived Price & 0.201 & 0.075 & 2.203 & 0.028 & H6 accepted \\
\hline Loyality & $<---$ & Satisfaction & 0.298 & 0.089 & 2.486 & 0.013 & H7 accepted \\
\hline
\end{tabular}

The table above explains the results of estimates that have been made by AMOS software. It has been obtained from 7 hypotheses that have been developed, obtained results that all hypotheses are accepted.

\section{Discussion}

The first hypothesis shows that the perceived quality variable is proven to have a significant and positive effect on customer satisfaction as indicated by the estimated coefficient of 0.340 with a probability of $p=0.000<0.05$. Thus supporting the first hypothesis (H1) so that it can be interpreted that the higher the perceived quality of the Iphone product, the higher customer satisfaction in using this product. This is because in buying a product consumers always want to feel a high value. As a criterion to get a high value, customers have hope for the value of goods to be consumed so that it will affect their satisfaction with the product or service. Kotler and Armstrong (2012) also argue that good quality products will create customer satisfaction. In turn, customers are happy, loyal and will recommend to others about the company and its products. The results of this study support the Dib and Al-Msallam (2015) research found that perceived quality has a positive and significant effect on customer satisfaction. 
The second hypothesis shows that the brand image variable proved to have a significant and positive effect on customer satisfaction as indicated by an estimate coefficient of 0.340 with a probability of $p=0,000<0.05$. Thus the brand image variable has a significant and positive effect on customer satisfaction, and these results support the second hypothesis (H2). This means that the higher the brand image on Iphone products, the more customer satisfaction will be and if the Iphone brand image gets lower then customer satisfaction will be weaker. Brand image is believed to create an effect on customer satisfaction. When customers are satisfied with existing products and services, their attitude towards Iphone products will increase. This attitude will then affect the satisfaction they feel on the Iphone product. Some research results show that company image has a significant influence on customer satisfaction. To avoid big risks, customers prefer to buy from products that have a good image. With the existence of a good product image helps people make the decision to transact on these products. The results of the study support the research of Suryati and Krisna (2015) and Lasander's (2013) study found that brand image had a significant effect on customer satisfaction.

The third hypothesis shows that price perceptions prove to have a significant and positive effect on customer satisfaction as indicated by an estimate coefficient of 0.281 with a probability of $p=0,000<0.05$. Thus this result supports the third hypothesis (H3), which means that the better the perception of UMY students about the price, the satisfaction achieved will increase, and vice versa the perception of price that is not good will reduce customer satisfaction. Price perception refers to the consumer's assessment of whether the seller's price is reasonable, acceptable or justifiable (Dib and Al-Msallam, 2015). Price loyalty is a very important problem that leads to satisfaction. Charging fair prices helps develop customer satisfaction and loyalty. The price perception that is good in the customer's mind is not necessarily that the product is of low price or vice versa, but there is a corresponding price with what the customer expects. Prices can be a quality indicator where high quality products will be bold at high prices. The results of the study support the research of Dib and Al-Msallam (2015) and the research of Suryati and Krisna (2015) found that prices have a significant effect on customer satisfaction.

The fourth hypothesis shows that the perceived quality variable is proven to have a significant and positive effect on brand loyalty as indicated by the estimate coefficient of 0.316 with a probability of $p=0.006<0.05$. Thus this result supports the fourth hypothesis (H4), meaning that the better the perceived quality of Iphone products, the loyalty of UMY students in using Iphone products will increase, and vice versa the perception of poor quality will reduce their loyalty. According to Bei and Chiao (2001), loyalty the brand shows the behavior expected in relation to the product or service, thus the quality of the product can shape the consumer's loyal attitude towards certain products. Positive perceived quality will encourage consumers to buy and create loyalty to the product. Furthermore, considering that consumer perceptions can be predicted, if the perception of quality is negative, the product will not be liked and will not last long in the market. Conversely, if the perception of customer quality is positive then the product will be preferred (Durianto and Darmadi, 2011). Thus, the higher the perception of customer quality will tend to encourage consumers to be loyal to the product that has been perceived so that it can be said that the perception of quality is related to brand loyalty. The results of this study support the study of Pramono (2011), and Utami and Saryadi, (2016) consistently found that perceived quality has a significant positive effect on brand loyalty.

The fifth hypothesis shows that the brand image variable proved to have a significant and positive effect on brand loyalty as indicated by the estimate coefficient of 0.306 with a probability of $p=0.006<0.05$. Thus the brand image variable has a significant and positive effect on brand loyalty, this result supports the fifth hypothesis (H5). The connecting theory between brand image and brand loyalty is quoted from Rangkuti (2006) which says that if a customer thinks that a particular brand is physically different from a competitor's brand, the brand image will be attached continuously so that it can form a certain brand loyalty called brand loyalty. Brand image influences consumers 'minds through a combination of advertising, public relations, physical images, word of mouth comments and consumers' real experiences with products or services. A good or positive image will have a good impact or influence on the product provided by consumers, namely loyalty to the product, and vice versa, a bad or negative image will have a bad influence on the product. Thus it is clear that an image, both positive and negative, will influence brand loyalty. The results of the study support the research of Dib and Al-Msallam (2015), Pramudyo (2012) found that brand image has a significant positive effect on brand loyalty.

The sixth hypothesis shows that the price perception variable is proven to have a significant and positive effect on brand loyalty indicated by an estimate coefficient of 0.201 with a probability of $p=0.028<0.05$. Thus the price perception variable has a significant and positive effect on brand loyalty, this result supports the sixth hypothesis (H6). This means that the better the perceived price perceived by UMY students, the higher brand loyalty and conversely the lower the perception of the price of Iphone products, the lower the brand loyalty. This result is in accordance with the findings of Ti Bei and Ching Chiao (2006) who find that fair price perceptions have a positive influence both directly and indirectly (through customer satisfaction) on brand loyalty. From the customer's perspective, price is what is given or sacrificed to get a product. It is possible to display repeat purchase behavior intentions. On the other hand, if customers do not feel that their sacrifice is valuable, they may not buy again, even when they are satisfied with the quality of a product if the price does not provide justice will reduce 
brand loyalty. In the research of Suryati and Krisna (2015) found that prices significantly influence brand loyalty. The seventh hypothesis can be seen that the perception of prices proved to have a significant and positive effect on brand loyalty indicated by an estimate coefficient of 0.201 with a probability of $p=0.028<0.05$. Thus the price perception variable has a significant and positive effect on brand loyalty, this result supports the sixth hypothesis (H6). This means that the better the perceived price perceived by UMY students, the higher brand loyalty and conversely the lower the perception of the price of Iphone products, the lower the brand loyalty. The existence of a significant positive influence on consumer satisfaction with consumer loyalty, this is in accordance with the opinions expressed by Bei and Chiao (2001) found that customer satisfaction has a positive influence on customer memories of an item or service so that customers will return to use the goods or services. If the product or service performance is lower than the customer's expectations, the customer is not satisfied. When achievement exceeds expectations, customers will feel very happy. Satisfied customers will buy again and they tell others about the good experience about the product. The key is to meet customer expectations with company achievements. Smart companies have the goal of making customers happy by only promising what they can submit, then giving more than they promised. The results of the study in accordance with the research of Utami and Saryadi, (2016), Pramono, (2011) and Ongkowidjoyo Helen (2015) found positive evidence that there is a relationship between customer satisfaction and brand loyalty.

\section{Conclusion And Limitations}

The results of the study found that there was a positive and significant effect of perceived quality on customer satisfaction, there was a positive and significant influence on brand image on customer satisfaction, there was a positive and significant influence on price perception of customer satisfaction, there was a positive and significant effect on product quality on brand loyalty, there is a positive and significant influence of brand image on brand loyalty, there is a positive and significant influence of price perception on brand loyalty and there is a significant influence partially on variable customer satisfaction on brand loyalty on Iphone Smartphone products.

This study has several limitations including abnormal data in multivariate testing, so that future researchers can use larger samples which are expected to be normally distributed in both univariate and multivariate data. Research that is only limited to the UMY campus, then future research is expected to cover a wider area, for example using samples for students on several campuses. Likewise with Iphone products still in general so that future research is expected to focus more on one of the iPhone series so that each segment can be known.

\section{References}

Aaker, David A. (2013). Manajemen Pemasaran Strategi. Edisi kedelapan. Salemba. Empat. Jakarta.

Aydin, Serkan, and Ozer, Gokhan. (2006). "National customer satisfaction indices : an implementation in the Turkish mobile telephone Market”. Marketing Intellegence \& Planning, 23(5):486-504

Dib Haan, Al-Msallam Salman, (2015), The Effects of the Determinants of Customer Satisfaction on Brand Loyalty, Journal of Research in Business and Management Volume 3, Issue 3 pp: 01-12

Durianto, Darmadi, (2011), Strategi Menaklukkan Pasar Melalui Riset Ekuitas dan Perilaku Merek, Cetakan XX, Jakarta: PT. Gramedia Pustaka Utama

Edris, Mochamad (2009), Pengaruh Kepercayaan Merek terhadap Loyalitas Merek (Studi Kasus pada Deterjen Merek Rinso di Kabupaten Kudus, Jurnal Analisis Manajemen Fakultas Ekonomi Universitas Muria Kudus, ISSN : $1979-6889$

Ferdinand Augusty, (2006), Metode Penelitian Manajemen, Pedoman Penelitian ... Structural Equation Modeling (SEM) Sebuah Pengantar

Hermann, Andreas et al. (2007). The influence of price fairness on customer satisfaction: an empirical test in the context of automobile purchases. Journal of Product \& Brand Management, 16/1, pp49-58

Kotler, Philip dan K.L. Keller, (2007), Manajemen Pemasaran Jilid 1, Edisi Keduabelas, Indeks, Jakarta.

Kotler Philip, Amstrong Gary. (2013). Prinsip-prinsip Pemasaran, Edisi ke-12. Penerbit Erlangga

Lasander, Christian. (2013). Citra Merek, Kualitas Produk dan Promosi Pengaruhnya terhadap Kepuasan Konsumen pada Makanan Tradisional (Survey pada Industri Rumah Tangga Dodol Daging Pala Audia di Tahuna Kab. Sangihe). Jurnal EMBA. Vol. 1 No. 3 September 2013. Manado : Universitas Sam Ratulangi

Lie Ti Bei, Yu-Ching Chiao, (2006) "The determinants of customer loyalty: An analysis of intangible factors in three service industries", International Journal of Commerce and Management, Vol. 16 Issue: 3/4, pp.162177

Martin-Ruiz, D., and Rondan-Cataluna, F. J. (2008). The Nature and Consequenses of Price Unfairness in Service: A Comparison to tangible Goods. International Journal of Service Industry Management, Vol. 19 No. 3,pp. 325-352

Mowen dan Minor, (2012), Perilaku Konsumen Jilid 1, Edisi. Kelima (terjemahan), Erlangga, Jakarta.

Ongkowidjoyo Helen (2015) The Impact of Brand Equity towards Customer Loyalty of Starbucks: Testing the Role of Customer Satisfaction as the Mediate Variable, iBuss Management Vol. 3, No. 2, pp: 186-195 
Pramono Rendra Adi, (2011), Pengaruh Brand Awareness, Perceived Quality dan Brand Image terhadap Brand Satisfaction dan Brand Loyalty pada Jasa Biro Perjalanan Antar Kota di Kota Malang (Studi pada Pelanggan Biro Perjalanan Kirana Tour and Travel, Siluet Tours and Travel, dan Bali

Pramudyo Anung, (2012), Jurnal Pegaruh Citra Merek Terhadap Loyalitas Melalui Kepuasan Sebagai Intervening, JBMA, Vol.01 No.01, hal:1-16

Rangkuti, Freddy. (2006). Measuring Customer Satisfaction. Jakarta: PT Gramedia Pustaka Utama

Schiffman dan Kanuk. 2008. Perilaku konsumen. Edisi 7. Jakarta: Indeks

Sondoh, S. L., Omar, M. W., Wahid, N. A., Ismail, I., \& Haru, A. (2007). The Effect of Brand Image on Overall Satisfaction and Loyalty Intention in the Context of Color Cosmetic. Journal Asian Academy of Management, 12(1): $83-107$.

Suryati Lili and Krisna Nandan Lima, (2015), Determinants Of Customer Satisfaction And Its Implication On Customer Loyalty (The Empirical Study Of Automotive Customer In Medan), IJABER, Vol. 13, No. 7 (2015): 5045-5066

Tjiptono, Fandy. (2010), Strategi Pemasaran, Edisi 2, Andi Offset, Yogyakarta

Utami Diah Tri dan Saryadi, (2016), Pengaruh Kesadaran Merek, Persepsi Kualitas Dan Asosiasi Merek Terhadap Loyalitas Merek Melalui Kepuasan Konsumen Sebagai Variabel Intervening Pada Pengguna IM3 (Studi Pada Mahasiswa S1 Universitas Diponegoro Semarang), e-journal Jurusan Administrasi Bisnis - Fakultas Sosial dan Ilmu Politik Universitas Diponegoro Semarang

https://apjii.or.id/downfile/file/BULETINAPJIIEDISI05, (2016), Saatnya jadi pokok perhatian pemerintah dan industri, Buletin APJII, Edisi 05

https://www.winnetnews.com, Apa Yang Membuat Terjadinya Penurunan Punjualan Iphone? 